\title{
Maleic Acid
}

National Cancer Institute

\section{Source}

National Cancer Institute. Maleic Acid. NCI Thesaurus. Code C25951.

An organic salt or ester of maleic acid that could be conjug ated to free base

compounds/drugs to improve the physiochemical properties including stability, solubility and dissolution rate. $(\mathrm{NCl})$ 